\title{
VEGETATIONAL AND CLIMATIC HISTORY OF JACKSON HOLE AND VICINITY
}

\author{
Cathy Barnosky \\ Division of Earth Sciences \\ Carnegie Museum of Natural History \\ Pittsburgh, PA
}

\section{Objectives}

The objectives of this project, now in its second year, have not changed significantly from that of the proposal. Prior to this study, the late-Quaternary vegetation history of the northern Rocky Mountains had been inferred largely from isolated pollen records. These data suggested that conifer forests were established early in postglacial time and were little modified thereafter. The similarity of past vegetation to modern communities over a broad area gives rise to two hypothesis: (1) glacial refugia were close to the ice margin, and (2) vegetation soon colonized the deglaciated areas and has been only subtly affected by climatic perturbations since that time. It is the goal of this projject to test these hypotheses in the region of Grand Teton National Park.

The research underway seeks to document the late-glacial and postglacial vegetation of Jackson Hole and the Pinyon Peak Highlands in order to clarify the nature and composition of ice-age communities, the rate and direction of plant migrations during glacial retreat, and the stability of the vegetation to postglacial environmental changes. This information is necessary to assess the sensitivity of the Park's vegetation to natural disturbance and to understand the vegetational, climatic, and glacial history of the northern Rockies as a whole.

The basis for reconstructing past vegetation is the relationship between modern vegetation and pollen rain in the northern Rocky Mountains. Accordingly, another objective of this project has been to expand the data base of modem pollen samples from different elevations and vegetation types. This information will define the pollen signature for various communities in the region today and provide a means of recognizing these associations in the past. A study of the pollen rain is underway in the region of Grand Teton and Yellowstone National Parks, Teton National Forest, and the Beartooth Mountains. These data will be combined with those already published from Yellowstone and the Snake River Plain (Baker, 1976; Davis, 1981).

\section{Methods}

A detailed discussion of the methodology for this study is included in the proposal and therefore will not be repeated here. Continuous pollen records from dated lake-sediment cores are the primary data base for the fossil study. These records have been obtained from a network of sites in Jackson Hole and 
the Pinyon Peak Highlands, an area that extends from the southern margin of the former Yellowstone ice field to the ice divide (see Table 1 for site information). Cores were obtained with a square-rod piston corer from an anchored floating platform or from the bog surface.

Pollen percentages, pollen influx, and the occurrence of plant macrofossils are utilized to determine the ancival of important forest taxa to each site and to interpret changes in plant communities since deglaciation. Radiocarbon dating and tephrochronology provide the chronologic framework to correlate the pollen profies between sites.

Many pollen-rain studies have suffered from the fact that different types of sites (e.g., lake sediments, soil, moss polsters) have been sampled and compared, even though their pollen-trapping characteristics vary. In the current project, only lake surface sediments were sampled to facilitate comparison with the fossil pollen obtained in lake cores. Surface sediments have now been analyzed from 59 lakes. Samples were taken with a Hongve sampler from an inflatable raft in the deepest water. At each site, local vegetation, topography, and geology was also noted.

\section{$\underline{\text { Results }}$}

Modern pollen samples. A qualitative comparison of pollen percentages along an altitudinal gradient provides some insights into the relationship between modem pollen rain and vegetation:

1. Pine (Pinus) is the dominant pollen type at all elevations, proving that total abundance of pine is not a reliable criterion for identifying the vegetation of this region. Pollen preservation as well as Diploxylon and Haploxylon percentages, however, have interpretable patterns along an elevation transect. High percentages of indeterminate pine (either broken or damaged grains) were found in samples both above upper treeline and below lower treeline. Diploxylon-type pine pollen (attributed to $\underline{P}$. contorta) is best represented in the lower forest where lodgepole pine predominates. Haploxylon-type pine pollen, largely attributable to $\underline{P}$. albicaulis, is best represented above $2700 \mathrm{~m}$, in the subalpine forest.

2. Spruce (Picea) accounts for $>6 \%$ of the pollen sum at sites where the tree is present locally. Values between 2 and $6 \%$ may mean local presence, but less than that amount is usually from long-distance transport. Local presence of fir (Abies) coincides with pollen values $>2 \%$. Only in the lower forest zone do percentages of fir exceed those of spruce.

3. Douglas-fir (Pseudotsuga) pollen, even in small percentages, is a good indicator of local presence of the tree, and it is most abundant in low-elevation forests where the tree is common.

4. Grass (Gramineae) pollen is never more than $10 \%$ of the pollen rain. Its highest values, not surprisingly, occur in alpine and steppe vegetation, and at sites with extensive mansh vegetation. 


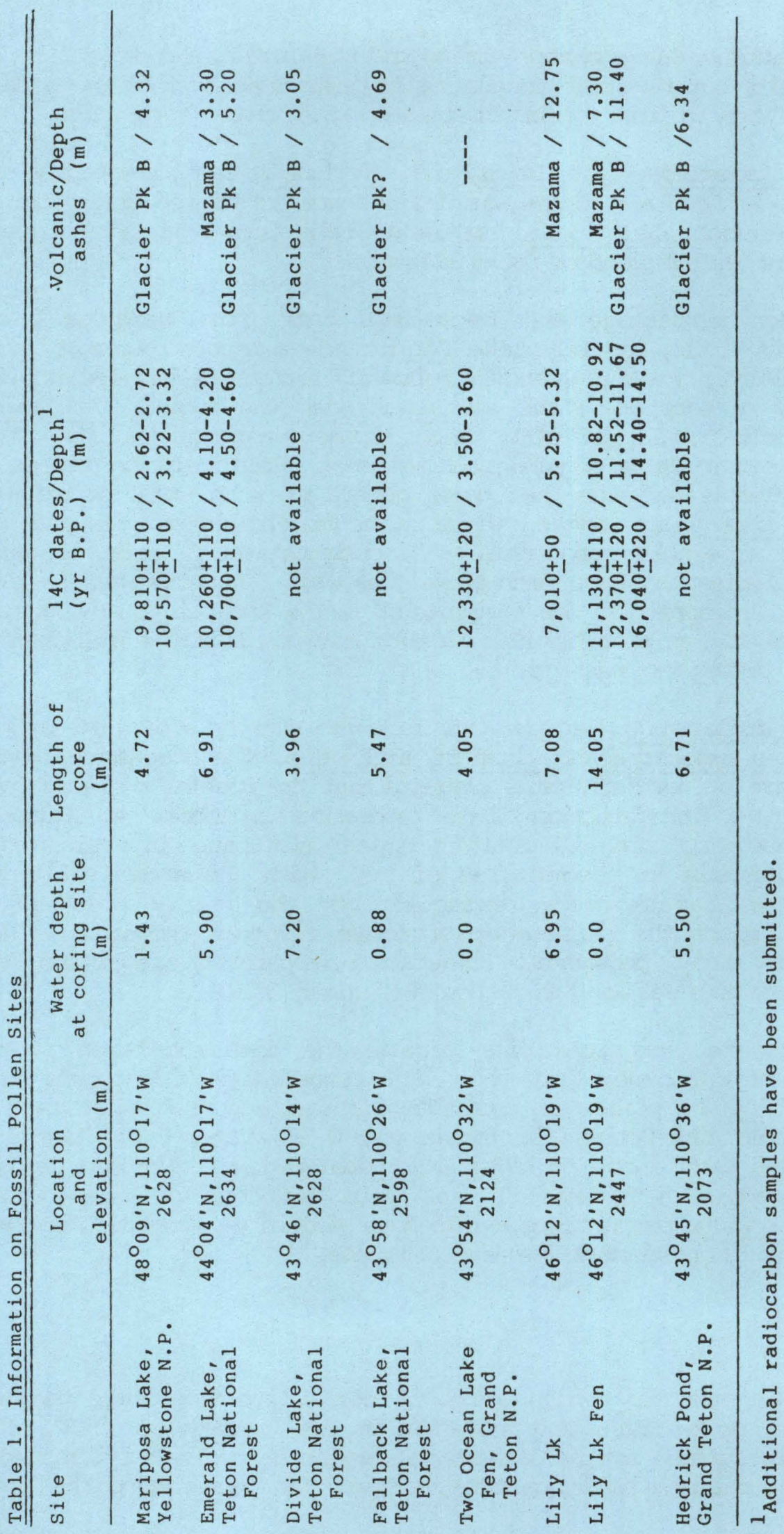


5. Artemisia, another large contributor to the pollen rain, shows no interpretable pattern, but its great abundance suggests that most of the pollen, even at high elevations, is from sagebrush species rather than alpine herbs.

6. Ploygonum bistortoides-type, Dryas. and Valeriana pollen consistently occur in subalpine parkland and alpine samples and are considered diagnostic of those types of vegetation. Selaginella densa and Cheilanthes-type spores appear only in samples from well-drained or rocky habitats.

Fossil sites. Pollen percentage and macrofossil data from Mariposa Lake, Emerald Lake, Divide Lake, and Lily Lake Fen provide a reconstruction of past vegetation in the Pinyon Peak Highlands. Following retreat of late-Pleistocene glaciers, a variety of herb and shrub species invaded the region. Artemisia, grasses, sedges, composites, and other herbs formed communities that most closely resemble modern alpine or subalpine meadows. Relatively low values of Pinus, Salix, and Getula suggests that these genera grew in small or isolated populations. Artemisia values exceed those in modern pollen samples and are attributed to such large pollen producers as A. tridentata or A. cana, although alpine worm wood species may have been present as well. Juniperus was the first conifer to become widespread in the region, and, in the absence of competition from other conifers, it was probably able to take advantage of the well-drained substrates created during ice wastage.

By $11.2 \mathrm{ka}$ Picea englemannii was present, followed shortly afterward by the appearance of Abies lasiocarpa and Pinus cf. albicaulis. The successively later anrival of these taxa at northerly sites suggests that the species migrated from the south and followed the direction of the retreating ice lobes. At Mariposa Lake, the most northerly site, all conifers appear simultaneously, confirming that it was the last site to become free of ice. With the arrival of trees, meadow communities became more restricted, but the steady presence of nonarboreal taxa implies the persistence of forest openings through the late Pleistocene. This early postglacial vegetation apparently resembled the spruce-fir-whitebark pine parkland at high elevations in GTNP.

In the early Holocene, lodgepole pine became the dominant taxon in the vegetation. Sites at lower elevations show high percentages of lodgepole pine, Pseudotsuga, and Populus pollen, an assemblage resembling the pollen rain of the modern lodgepole pine-Douglas fir forest at low elevations. The fact that these taxa extended their range to higher altitudes suggests increased drought conditions compared with today. In the late Holocene lodgepole pine, Pseudotsuga, and Populus percentages declined to modern values with the onset of cooler/more humid conditions in the late Holocene.

\section{Conclusions}

The results thus far are very encouraging. A correlation is possible between modern vegetation, pollen rain, and elevation in the vicinity of GTNP. The addition of the new surface sample data to pollen-rain data already pulclished is leading to a comprehensive and quantitative basis for interpreting the fossil record. 
Four fossil sites have been analyzed and provide a vegetation history of the Pinyon Peak Highlands. The available radiocarbon dates indicate that postglacial migration was very rapid and probably from the south. New records currently under study will help refine the patterns of plant migration. For example, Hedrick Pond just within the Burned Ridge Moraine should provide data on postglacial migrations from Jackson Hole. The late-glacial record from Fallback Lake on Whetstone Mountain will help determine whether unglaciated mountain tops served as refugia, allowing tree populations to spread downslope with postglacial warming.

In addition to their use in interpreting the pollen stratigraphy, radiocarbon dates of the basal sediments provide a more precise chronology for the deglaciation of the Yellowstone ice field. Tephra identifications serve as time markers in correlating cores and also help delineate the distribution of ash layers from volcanic eruptions in the Pacific Northwest.

\section{References Cited}

Baker, R. G. 1976. Late Quaternary vegetation history of the Yellowstone Basin, Wyoming. U.S. Geol. Surv. Prof. Paper 729-E.

Davis, O. K. 1981. Vegetation migration in southern Idaho during the Late Quaternary and Holocene. Ph.D. dissertation, Univ. of MN, Minneapolis. 